\title{
Role of Climatic Conditions on the Incidence of Varicella in an Out-patient Clinic of a Tertiary Care Pediatric Hospital at Dhaka
}

\author{
Mahfuza Hussain', Md. Nurul Amin'2, Md. Rafiqul Islam³
}

\section{ABSTRACT}

Background \& objective : Chicken pox or varicella is a disease of both tropical and temperate zones bearing a complex-relationship with climatic variables, like temperature, rainfall and relative humidity, wind velocity and so on. As no study has, by far, been conducted to relate its occurrence with these climatic variables in Bangladesh, this study was intended to explore the effect of weather conditions on the incidence of varicella in Dhaka city of Bangladesh.

Methods: The present cross-sectional study obtained data of 172 varicella cases from the records of the daily register of Out-patient Department of Dhaka Shisu Hospital, Dhaka between January 2018 to December 2019. According to the study protocol a child was diagnosed as having varicella or chicken pox who had a history of short febrile illness accompanied by a pruritic vesicular eruption (on the face and trunk)) of the skin and mucous membranes which ultimate weeps out and crusts. Total number of cases treated monthly at Out-patient Department (OPD) during the period was also recorded. Climatic data were provided by Bangladesh Meteorological Department, which among others, included monthly average temperature, relative humidity (RH) and amount of rainfall or precipitation. While the outcome variable was monthly number of varicella cases, the predictive variables were average temperature, humidity and rainfall during the study period.

Result: Over $70 \%$ of children were $1-10$ years old with median age of the children being 5.5 years (range: $<1$ month -14 years). Boys were a bit higher (54\%) than the girls (46\%). A seasonal pattern of chicken pox was seen with clustering of cases between mid-February to mid-April (spring season) with two peaks - one in February and another in April, when monthly average temperature, total rainfall and humidity all were at their optimum. The peak incidences of chicken pox cases during the spring both in 2018 and 2019 as correlated with climatic data of the same period, it is seen that the prevailing weather then was optimum-average temperature was $23^{\circ} \mathrm{C}$, average precipitation was $20-25 \%$ of the total annual precipitation and relative humidity was around $65 \%$.

Conclusion: The study concluded that majority of the varicella cases occur under ten years of age and boys are a little more susceptible to have the infection than the girls. A seasonal pattern of chicken pox is clearly seen with clustering of cases between mid-February to mid-April (spring season) with two peaks when monthly average temperature, total rainfall and humidity all are optimally favorable for the multiplication of varicella zoster virus. Key words: Varicella, climatic variables, temperature, rainfall, relative humidity etc.

\section{Authors' information:}

'Dr. Mahfuza Hussain, Consultant (Dermatology), Dhaka Shisu Hospital, Dhaka

${ }^{2}$ Dr. Md. Nurul Amin, Associate Professor (Research \& Development) \& Executive Editor, Ibrahim Cardiac Medical Journal, Ibrahim Cardiac Hospital \& Research Institute, Shahbag, Dhaka.

${ }^{3}$ Dr. Md. Rafiqul Islam, Resident Medical Officer, Dhaka Shisu Hospital, Dhaka.

Correspondence: Dr. Mahfuza Hussain, Phone:+88001711545007 E-mail: mafihaq@gmail.com 


\section{INTRODUCTION:}

Chicken pox (CP) or varicella is a mild, highly infectious disease, primarily of children, characterized clinically by a pruritic vesicular eruption (on the face and trunk) of the skin and mucous membranes which ultimate weeps out and crusts. ${ }^{1}$ It is an extremely contagious vaccine-preventable infectious disease, caused by the ubiquitous varicella-zoster virus (VZV), with cosmopolitan nature. ${ }^{2-5}$ Over $95 \%$ of infections with VZV result in symptomatic infection known as chickenpox, and more than $90 \%$ of individuals in temperate countries are infected with VZV before the age of 15 years. But infection occurs at different ages in different parts of the world. For example, over $80 \%$ of people are infected by 10 years of age in the United States, the United Kingdom, and Japan. ${ }^{6}$ Furthermore, a mortality rate of 2-3 per 100,000 infected persons has been reported. ${ }^{7}$ From an epidemiological point of view, chickenpox is a common epidemic disease of childhood in Japan, and shows a marked seasonality, namely high prevalence in winter and spring rather than in summer. ${ }^{8}$

Potential transmission of infectious diseases including chickenpox is believed to be affected by changes in climate. The increasing evidence for rapid global climate change has highlighted the need to examine the relationship between weather variability and infectious diseases incidence. Several studies have already examined the relationship between weather variability and the incidence of infectious diseases. ${ }^{5,9,10}$ However, the impact of weather fluctuations on varicella is still not well-understood and published evidence is inconsistent. For example, a study in Hong Kong found no significant association between temperature and varicella incidence, ${ }^{11}$ contrary to earlier studies in the West Indies ${ }^{12}$ that suggested that temperature was inversely correlated with the incidence of varicella. In Japan the previously reported chickenpox incidence was found to be associated with temperature. ${ }^{4}$ Studies from Mexico $^{13}$ and Taiwan ${ }^{14}$ have suggested that temperature is positively associated with varicella incidence. These differences are probably due to variation in weather patterns of the study areas and the different variables considered in the models. A recent study showed that atmospheric pressure and rainfall were positively associated with varicella incidence, ${ }^{15}$ but no other study has supported these findings. Furthermore, the relationship between varicella incidence and other meteorological variables, such as wind velocity and sunshine, rainfall, humidity has not yet been studied. Therefore, there remains an urgent need to investigate these relationships to help prediction of future occurrence and to develop early warning systems for varicella.

The present study was conducted to explore whether reported monthly chickenpox incidences in Bangladesh is dependent upon temperature, humidity and rainfall. The findings derived from the study might be useful to facilitate prediction of epidemics and preparation for the effects of climatic changes on the epidemiology of chickenpox in Bangladesh.

\section{METHODS:}

\section{Topographical feature of the study area:}

The climate of Bangladesh is subtropical in the center-north and tropical in the south, with a pleasantly warm and sunny winter from November to mid-February, a short spring between mid-February and April, and a long summer-monsoon season from May to October. The study was conducted in the capital city, Dhaka, which is located in central Bangladesh at $23^{\circ} 42^{\prime} \mathrm{N} 90^{\circ} 22^{\prime} \mathrm{E}$, on the eastern banks of the Buriganga River.

\section{Meteorological condition of the study area:}

Dhaka experiences a hot, wet and humid tropical climate. Under the Köppen climate classification, Dhaka has a tropical wet and dry climate. The city has a distinct monsoonal season, with an annual average temperature of $25^{\circ} \mathrm{C}\left(77^{\circ} \mathrm{F}\right)$ and monthly means varying between $18^{\circ} \mathrm{C}\left(64^{\circ} \mathrm{F}\right)$ in January and $29^{\circ} \mathrm{C}\left(84^{\circ} \mathrm{F}\right)$ in August. Approximately $87 \%$ of the annual average rainfall of 2,123 millimetres (83.6 inches) occurs between May and October. The wettest month for Dhaka is July with an average of $367.9 \mathrm{~mm}$ of precipitation falling while the driest month is December with $8.9 \mathrm{~mm}$ falling (Fig. 1-4). ${ }^{16}$ 


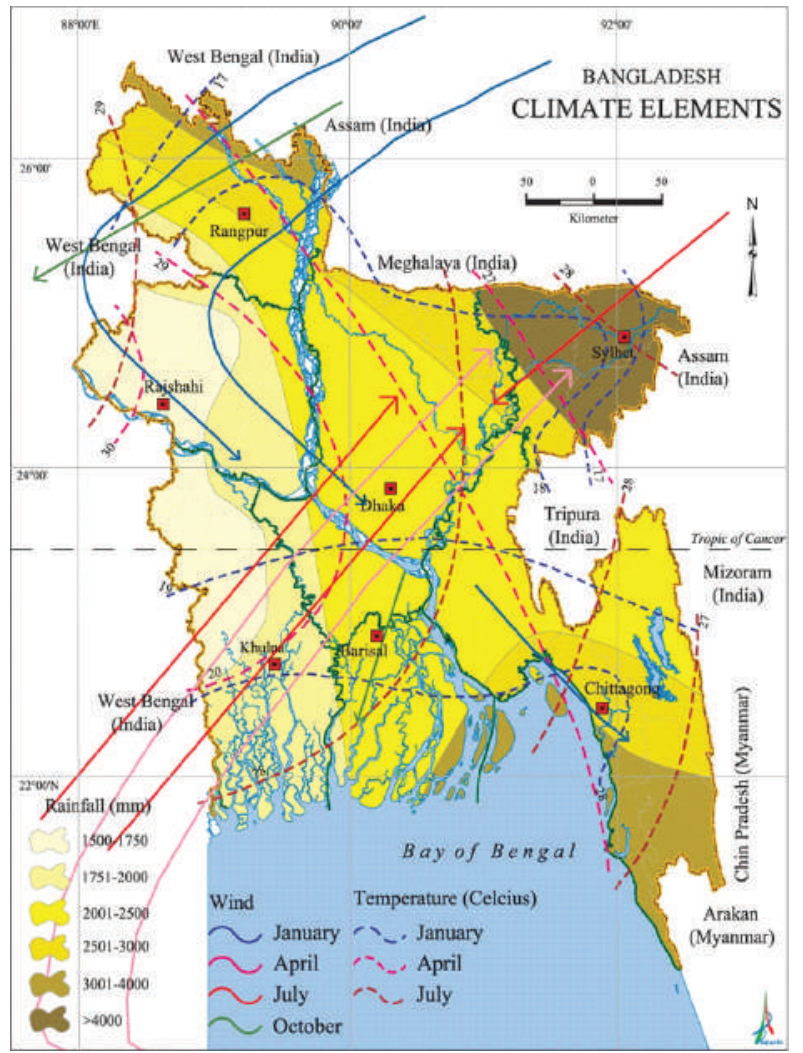

Fig. 1: Map of Bangladesh showing Climate Elements (Source:Climate-Bangladesh. National Encyclopedia, Bangladesh, Available at: en.banglapedia.org)



Fig. 2: Monthly average minimum maximum temperatures of Dhaka, Bangladesh



Fig. 3: Average relative humidity (RH) of Dhaka, Bangladesh

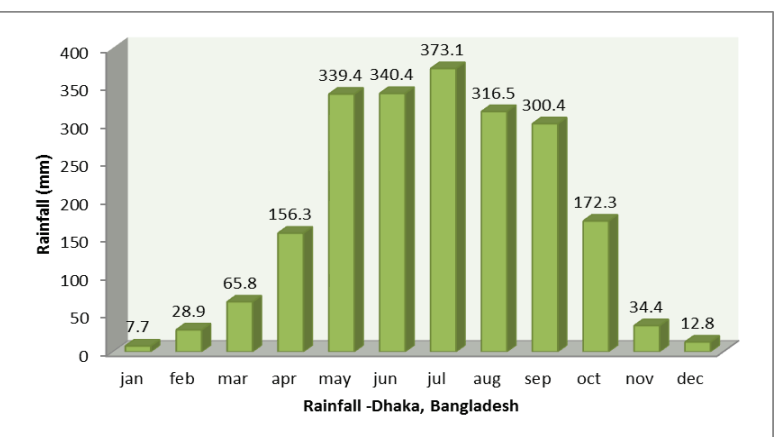

Fig. 4: Monthly average rainfall in Dhaka, Bangladesh

\section{Data collection:}

The data of varicella cases were collected from the Out-patient Department of Dhaka Shisu Hospital, a Tertiary Pediatric Hospital in Dhaka City, over a period of 2 years between January 2018 to December 2019. The study protocol defined a case of varicella as a child with a history of brief febrile illness accompanied by a pruritic vesicular eruption (on the face and trunk) of the skin and mucous membranes (of mouth and conjunctiva) which ultimately weeps out and crusts. Once identified, a patient was treated either at the OPD setting or was admitted in the In-patient isolation ward, depending on the severity of the condition. Total number of varicella cases were recorded monthly during the study period. Meteorological data were provided by Bangladesh Meteorological Department, under Ministry of Defense of the Government of Bangladesh, which among others, included monthly average temperature $\left({ }^{\circ} \mathrm{C}\right)$, relative humidity $(\%)$ and amount of precipitation or rainfall $(\mathrm{mm})$. While the outcome variable was the monthly number of varicella cases, the predictive variables were average temperature, humidity and rainfall during the study period. Data were analyzed using SPSS (Statistical Package for Social Sciences), version 25.0. The test statistics used to analyze the data were descriptive statistics. While qualitative data were expressed in frequency and percentage, the quantitative data were presented as median, standard error of mean and range.

\section{RESULTS:}

Age distribution of the children with chicken pox shows that over one-third (36\%) of the children 
were 1 - 5 years old and another one-third $(34.3 \%)$ was $5-10$ years together comprising $>70 \%$ of the cases with median age of the patients being $5.5 \pm$ 0.3 years (range: < 1 month -14 years). Boys outnumbered girls by 11:9 (Table I).

Table II \& III and Fig. 5 describe the month-wise distribution of chicken pox (CP) cases with respect to climatic variables. There were clustering of varicella cases between mid-February to mid-April (spring season) with two peaks - one in February and another in April when monthly average temperature, total rainfall and humidity all were at minimum compared to those in May to October (rainy season) of the year. The clustering of cases was more intense in the year 2019 than that in the year 2018 as reflected in the graph of the time distribution of the varicella cases (Fig. 5). During the period (November to April in 2018) mean monthly temperature was $23.3^{\circ} \mathrm{C}$, mean rainfall was $20.7 \%$ of the total annual precipitation and mean relative humidity was $66.2 \%$. During the same period in 2019, the mean monthly temperature was $23.1{ }^{\circ} \mathrm{C}$, mean rainfall was $25.2 \%$ of the total annual precipitation and mean relative humidity was $63.3 \%$. The proportion of chicken pox cases out of total cases treated during the dry season (winter, spring and early summer) was $1.7 \%$ in 2018 and was 3.3\% in 2019, which in the rainy seasons (May to October) was $0.7 \%$ and $0.8 \%$ in 2018 and 2019 respectively (Table IV).



Fig. 5: Chicken pox cases presented in 2018 through 2019 stratified by months

\begin{tabular}{|c|c|c|}
\hline Demographics & Frequency & Percentage \\
\hline \multicolumn{3}{|l|}{ Age $^{*}$ (years) } \\
\hline$<1$ & 18 & 10.5 \\
\hline $1-5$ & 62 & 36.0 \\
\hline $5-10$ & 59 & 34.3 \\
\hline$\geq 10$ & 33 & 19.2 \\
\hline \multicolumn{3}{|l|}{ Sex } \\
\hline Male & 93 & 54.1 \\
\hline Female & 79 & 45.9 \\
\hline
\end{tabular}

Table II. Seasonal variation of chicken pox cases in 2018 stratified by month

\begin{tabular}{lcccc}
$\begin{array}{l}\text { Year } \\
2018\end{array}$ & $\begin{array}{r}\text { Number } \\
\text { of Cases }\end{array}$ & $\begin{array}{c}\text { Monthly average } \\
\text { temperature }\left({ }^{\circ} \mathrm{C}\right)\end{array}$ & $\begin{array}{c}\text { Monthly total } \\
\text { rain fall }(\mathrm{mm})\end{array}$ & $\begin{array}{c}\text { Monthly average } \\
\text { relative humidity (\%) }\end{array}$ \\
\hline January & 01 & 17.5 & 0.0 & 69.4 \\
February & 10 & 23.2 & 20.0 & 62.1 \\
March & 07 & 27.3 & 3.0 & 60.2 \\
April & 15 & 27.3 & 309.0 & 70.0 \\
May & 13 & 27.6 & 392.0 & 79.6 \\
June & 06 & 29.4 & 366.0 & 82.0 \\
July & 00 & 29.3 & 354.0 & 82.2 \\
August & 00 & 29.8 & 141.0 & 78.5 \\
September & 00 & 29.8 & 76.0 & 77.7 \\
October & 02 & 27.3 & 45.0 & 72.7 \\
November & 00 & 24.2 & 13.0 & 69.0 \\
December & 01 & 20.3 & 13.0 & 66.5
\end{tabular}

Table III. Seasonal variation of chicken cases in 2019 stratified by month

$\begin{array}{lcccc}\begin{array}{l}\text { Year } \\ 2019\end{array} & \begin{array}{c}\text { Number } \\ \text { of Cases }\end{array} & \begin{array}{c}\text { Monthly average } \\ \text { temperature }\left({ }^{\circ} \mathrm{C}\right)\end{array} & \begin{array}{c}\text { Monthly total } \\ \text { rain fall }(\mathrm{mm})\end{array} & \begin{array}{c}\text { Monthly average } \\ \text { relative humidity (\%) }\end{array} \\ \text { January } & 15 & 20.2 & 1.0 & 60.3 \\ \text { February } & 30 & 22.0 & 115.0 & 63.6 \\ \text { March } & 17 & 26.0 & 39.0 & 62.1 \\ \text { April } & 27 & 28.3 & 212.0 & 70.2 \\ \text { May } & 12 & 29.8 & 231.0 & 73.6 \\ \text { June } & 03 & 29.9 & 242.0 & 79.4 \\ \text { July } & 04 & 29.3 & 383.0 & 82.7 \\ \text { August } & 06 & 29.9 & 223.0 & 79.4 \\ \text { September } & 01 & 29.1 & 161.0 & 81.0 \\ \text { October } & 00 & 27.6 & 188.0 & 78.6 \\ \text { November } & 00 & 20.2 & 1.0 & 60.3 \\ \text { December } & 02 & 22.0 & 115.0 & 63.6\end{array}$




\begin{tabular}{|c|c|c|c|c|c|c|c|}
\hline Year & $\begin{array}{l}\text { (Total CP cases } \\
\text { in dry season)/ } \\
\text { (Total of all cases } \\
\text { in dry season) }\end{array}$ & $\begin{array}{l}\text { Proportion of CP } \\
\text { morbidity out of } \\
\text { total morbidity in } \\
\text { dry season }\end{array}$ & $\begin{array}{l}\text { (Total CP cases in } \\
\text { rainy season)/ } \\
\text { (Total of all cases in } \\
\text { rainy season) }\end{array}$ & $\begin{array}{l}\text { Proportion of CP } \\
\text { morbidity out of } \\
\text { total morbidity } \\
\text { in rainy season }\end{array}$ & $\begin{array}{l}\text { Monthly total } \\
\text { rainfall (mm) } \\
\text { in dry/rainy } \\
\text { season }\end{array}$ & $\begin{array}{c}\text { Monthly average } \\
\text { temp. }\left({ }^{\circ} \mathrm{C}\right) \\
\text { in dry/rainy } \\
\text { season }\end{array}$ & $\begin{array}{l}\text { Monthly average } \\
\mathrm{RH}(\%) \text { in dry/ } \\
\text { rainy season }\end{array}$ \\
\hline 2018 & $34 / 2006$ & $1.7 \%$ & $21 / 2852$ & $0.7 \%$ & $23.3 / 28.9$ & $59.6 / 229$ & $66.2 / 78.8$ \\
\hline 2019 & $91 / 2694$ & $3.3 \%$ & $26 / 3218$ & $0.8 \%$ & $23.1 / 29.2$ & $80.5 / 238$ & $63.3 / 79.1$ \\
\hline
\end{tabular}

\section{DISCUSSION:}

The present study was aimed at examining the role of meteorological variables on chicken pox occurrence in Bangladesh. In this study over $70 \%$ of children were 1-10 years old with median age of the children being 5.5 years (range: $<1$ month 14 years). Boys outnumbered girls by 11:9. Chicken pox is called an ageless disease and there is wide variation in age distribution of chicken pox cases. Breuer and Fifer ${ }^{6}$ reported that over $80 \%$ of people are infected by 10 years of age in the United States, the United Kingdom, and Japan. In Wuhan the 5-19-year age group accounted for $60-70 \%$ of all cases of chicken pox from 2007 to 2015 and in Hong Kong the 6-17-year age group comprised of $52.4 \%$ of all chicken pox cases $^{17}$, while in Japan $78 \%$ of all reported chicken pox cases during 2009-2011 were in pre-school children (0-4 years old). ${ }^{4}$ However, many people have been infected by 20 to 30 years of age in China, India, Southeast Asia, and the West Indies. Even a 97-year-old woman recently presented with 4-day history of vesicular rash, initially at the feet but then spread up to the thighs bilaterally, abdomen and trunk and was diagnosed as bullous pemphigus and cellulitis by the emergency department. But later on, varicella zoster virus (VZV) infection was confirmed by the dermatology team and the positive VZV DNA swabs (Fig. 6). ${ }^{18}$ In our countries as well many adult people are infected, but as the present study was conducted in the pediatric hospital, we did not find any case of adult age. Former to use of the varicella vaccine, most cases of chickenpox occurred in persons younger than 15 years of age. ${ }^{19}$

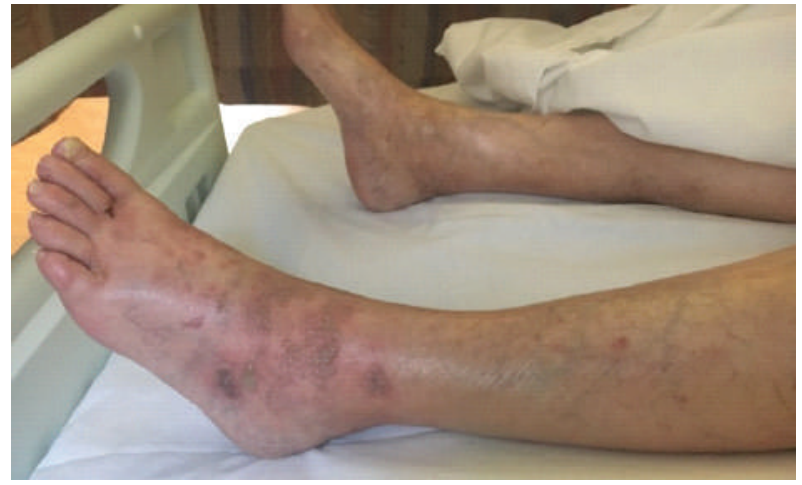

Fig.6: Rash on foot and torso with vesicles present (Adapted from Mathew et al., 2018)

Our study demonstrated a seasonal pattern of varicella occurrence with a higher number of cases occurring in the spring season (from mid-February to April) with bimodal distribution (one peak in the mid-February and another in the mid-April) and a few cases in winter (November to January) and summer and rainy seasons (May to October). The peak incidences of chicken pox cases during the spring both in 2018 and 2019 when correlated with climatic data of the same period, it is quite evident that the prevailing weather then was optimum-average temperature was $23^{\circ} \mathrm{C}$, average precipitation was $20-25 \%$ of the total annual precipitation and average relative humidity was $65 \%$, which might have favorably influenced the multiplication and transmission of Varicella Zoster virus. Ullah and associates ${ }^{20}$ in a seasonality analysis of chicken pox in Bangladesh showed that the disease increases insidiously from January and peaks at May and thereafter it decreases rapidly. From August to November the disease is almost absent but from January, it again starts going up giving a cyclical pattern with unimodal distribution. The Encyclopedia of Science \& Technology also noted that the disease had annual 
cycles, peaking in the spring of each year. ${ }^{19}$

In the study of Chen et al, ${ }^{21}$ bimodal cycles of reported chickenpox incidences were clearly observed in areas of northern Japan such as Hokkaido (latitude $43^{\circ} \mathrm{N}$ ) disappeared at lower latitudes, and unimodal cycles appeared in Okinawa Prefecture, the most southern prefecture in Japan (latitude $26^{\circ} \mathrm{N}$ ). This transition of patterns of reported chickenpox incidences in Japan was considered to be temperature-dependent. Shoji et $\mathrm{al}^{22}$ who showed that the reported cases of chickenpox increased at $5^{\circ} \mathrm{C}-20^{\circ} \mathrm{C}$ (i.e., the temperature range at which the chickenpox virus is activated) and decreased at temperatures lower than $5^{\circ} \mathrm{C}$ and higher than $20^{\circ} \mathrm{C}$. In Wuhan, where the temperature falls below $5^{\circ} \mathrm{C}$ in winter and exceeds $20^{\circ} \mathrm{C}$ in summer, the occurrence of epidemics is bimodal. In contrast, the occurrence of epidemics is expected to be unimodal in Hong Kong, where the temperature rarely falls below $5^{\circ} \mathrm{C}$ in winter; however, it was actually bimodal.

Based on the findings of the present study and the findings of other studies compared and contrasted so far, we need to reach a conclusion. But before coming to a conclusive remark, the limitations of the study deserve mention.

\section{Limitations:}

- The present study analyzed only two-year (2018-2019) data of chicken pox presented in a single tertiary pediatric hospital of Dhaka city which does not seem to be enough to describe the influence of climatic variables on chicken pox incidences in whole Bangladesh. It would be useful to conduct a time series analysis over a longer period of time to determine the effect of meteorological variables on the occurrences of chicken pox in our country.

- Besides, data collected from the out-patient register may not represent the complete picture of chicken pox presented in the OPD. There may be other pediatricians in the same hospital who might have treated chicken pox cases but their treatment data might not have been recorded in this register.
- Additionally, chicken pox patients with mild or subclinical forms might not have been diagnosed as chicken pox cases.

\section{CONCLUSION:}

The study concluded that majority of the chicken pox cases acquire the infection by ten years of age and boys are a little more prone to acquire the infection than the girls. A seasonal pattern of chicken pox is seen with clustering of cases between mid-February to mid-April (spring season) with two peaks when monthly average temperature, total rainfall and humidity all remains optimum for the multiplication of VZV. A large-scale study, with inclusion of other meteorological variables and human behavioral factors, is deemed essential to study the seasonal variation and transmission dynamics of chicken pox in Bangladesh.

\section{REFERENCES:}

1. Lawrence DG. Varicella - zoster virus, clinical aspects. In: Roizman B, Whiteley RJ, Lopez C, eds. The human herpesviruses. New York: Raven Press, Ltd., 1993.

2. Lopez A, Schmid S, Bialek S. Manual for the surveillance of vaccine-preventable diseases, chapter 17: Varicella. 2011. Available at: https://www.cdc.gov/vaccines/ pubs/surv-manual/chpt17-varicella.pdf

3. Council of State and Territorial Epidemiologists. Position statement 09-ID-68. Public health reporting and National Notification for Varicella: CSTE; 2009. Available at:http://c.ymcdn.com/sites/www.cste.org/resource/ resmgr/PS/09-ID-68.pdf. Accessed 6 July 2019.

4. Harigane K, Sumi A, Mise K, Kobayashi N. The role of temperature in reported chickenpox cases from 2000 to 2011 in Japan. Epidemiol Infect 2015;143:2666-2678. doi: $10.1017 /$ S095026881400363X.

5. Yang $Y$, Geng X, Liu X, Wang W, Zhang J. Association between the incidence of varicella and meteorological conditions in Jinan, eastern China, 2012-2014. BMC Infect Dis 2016;16:179. doi: 10.1186/ s12879-016- 1507-1.

6. Breuer J, Fifer H. Chickenpox. BMJ Clin Evid 2011; 2011:0912.

7. Boelle PY, Hanslik T. Varicella in non-immune persons: incidence, hospitalization and mortality rates. Epidemiol Infect 2002;129:599-606. doi: 10.1017/ S0950268802007720.

8. Shoji M, Tsunoda A, Ishida N. Correlation between the occurrence of infantile infectious diseases and the weather. Kosankinbyo Kenkyusho Zasshi 1987;38:92- 101. 
9. Wu PY, Li YC, Wu HD. Risk factors for chickenpox incidence in Taiwan from a large-scale computerized database. Int J Dermatol 2007;46:362-366. doi: 10.1111/j.1365-4632.2006.03050.x.

10. Chen B, Sumi A, Toyoda S, Hu Q, Zhou D, Mise K, Zhao J, Kobayashi N. Time series analysis of reported cases of hand, foot, and mouth disease from 2010 to 2013 in Wuhan, China. BMC Infect Dis 2015;15:495-499. doi: 10.1186/s12879-015-1233-0.

11. Chan JY, Tian L, Kwan Y, Chan W, Leung C. Hospitalizations for varicella in children and adolescents in a referral hospital in Hong Kong, 2004 to 2008: a time series study. BMC Public Health 2011;11:366. doi: 10.1186/1471-2458-11-366.

12. Garnett GP, Cox MJ, Bundy DA, Didier JM, St CJ. The age of infection with varicella-zoster virus in St Lucia, West Indies. Epidemiol Infect 1993;110(2):361-72. doi: 10.1017/S0950268800068308.

13. Vergara-Castaneda A, Escobar-Gutierrez A, Ruiz-Tovar K, Sotelo J, Ordonez G, Cruz-Rivera MY, FonsecaCoronado S, Martinez-Guarneros A, Carpio-Pedroza JC, Vaughan G. Epidemiology of varicella in Mexico. J Clin Virol 2012;55(1):51-7.doi:10.1016/j.jcv.2012.06.004.

14. Wu PY, Li YC, Wu HD. Risk factors for chickenpox incidence in Taiwan from a large-scale computerized database. Int J Dermatol 2007;46(4):362-6. doi:10. $1111 /$ j.1365-4632.2006.03050.x.

15. Chan JY, Lin HL, Tian LW. Meteorological factors and El Nino Southern Oscillation are associated with paediatric varicella infections in Hong Kong, 2004-2010. Epidemiol Infect 2014;142(7):1384-92. doi: 10.1017/ S0950268813002306.
16. Weather base. Historical Weather for Dhaka, Bangladesh. weatherbase.com. Retrieved 15 December 2008.

17. JYC C, Leung KM, WWS T, Lee A. Varicella vaccine uptake and asscoated fatocrs in children in Hong Kong. Epidemiol Infect 2014;142:994-1001. doi: 10.1017/ S0950268813001994.

18. Navaratnam AMD, Ma N, Farrukh M, Abdulla A. Chickenpox: an ageless disease. BMJ Case Rep 2017; 2017:bcr-2017-222027.doi:10.1136/bcr-2017-222027.

19. Infectious disease. McGraw-Hill Encyclopedia of Science and Technology, 2005. Available at: http://en. wikipedia.org/wiki/McGrawhill_Encyclopedia_of_Scienc e_and_Technology.

20. Ullah MO, Uddin MJ, Rahman M, Islam MN, Uddin MT. A Study to detect the seasonal effect of chickenpox in Bangladesh. Romanian Statistical Review 2009;12: 61-66.

21. Chen B, Sumi A, Wang L, Zhou W, Kobayashi N. Role of meteorological conditions in reported chickenpox cases in Wuhan and Hong Kong, China. BMC Infect Dis 2017;17(1):538. doi:10.1186/s12879-017-2640-1.

22. Shoji, M, Tsunoda, A, Ishida, N. Correlation between the occurrence of infantile infectious diseases and the weather [in Japanese]. Journal of Tuberculosis and Leprosy 1986;38:91-101. 